\title{
ETIOLOGÍA VIRAL DE LAS INFECCIONES RESPIRATORIAS AGUDAS GRAVES EN UNA UNIDAD DE CUIDADOS INTENSIVOS PEDIÁTRICOS
}

\author{
María Becerra ${ }^{1, a}$, Victor Fiestas², b, José Tantaleán ${ }^{1,3, a}$, Gabriela Mallma1,c, Margarita Alvarado ${ }^{1, d}$, Victoria Gutiérrez²,e \\ Maribel Huaringa ${ }^{2, f}$, Nancy Rojas ${ }^{2, e}$
}

\begin{abstract}
RESUMEN
Objetivos. Identificar los principales agentes etiológicos virales en pacientes con infección respiratoria aguda grave (IRAG) hospitalizados en una Unidad de Cuidados Intensivos Pediátricos (UCIP) y analizar sus características clínicas. Materiales y métodos. Estudio longitudinal prospectivo en menores de cinco años hospitalizados por IRAG en la UCIP del Instituto Nacional de Salud del Niño en Lima, Perú. Se realizaron pruebas de inmunofluorescencia directa y RT-PCR en tiempo real para el diagnóstico de virus respiratorios en muestras de aspirado traqueal o hisopado nasofaríngeo. Resultados. Se incluyeron 117 pacientes. La mediana de edad fue cuatro meses, el $66 \%$ presentaron comorbilidad y el $91 \%$ requirieron ventilación mecánica. Se identificó monoinfección por virus respiratorios en el $47 \%$ y coinfección viral en el 2,6\%, siendo el virus sincicial respiratorio subtipo A (VSR-A) el más frecuente. La mediana del tiempo de hospitalización fue de 21 días y 20 (17\%) pacientes fallecieron. Se encontró asociación entre el antecedente de enfermedad pulmonar crónica y la infección por el VSR-A $(p=0,045)$ y entre el síndrome de Down y la infección por virus influenza $A(p=0,01)$. Después de controlar por potenciales factores de confusión, se halló que la cardiopatía congénita (RR: 3,1; IC 95\%: 1,3-5,8; $p=0,002$ ) y la infección nosocomial (RR: 2,6; IC 95\%: 1,0-5,3; $p=0,01$ ) incrementaron el riesgo de muerte en pacientes con IRAG. Conclusiones. EI VSR-A fue la etiología viral más frecuente en menores de cinco años hospitalizados por IRAG en la UCIP. No se encontró asociación entre la infección viral y la sobrevida del paciente.
\end{abstract}

Palabras clave: Virus Sincitial Respiratorio Humano; Reacción en Cadena en Tiempo Real de la Polimerasa; Unidades de Cuidado Intensivo Pediátrico; Perú (Fuente: DECS BIREME).

\section{VIRAL ETIOLOGY OF SEVERE ACUTE RESPIRATORY INFECTIONS IN A PEDIATRIC INTENSIVE CARE UNIT}

\begin{abstract}
Objectives. To identify the main viral etiological agents in patients with severe acute respiratory infection (SARI) hospitalized in a Pediatric Intensive Care Unit (PICU) and to analyze their clinical characteristics. Materials and Methods. Prospective longitudinal study in children under five years of age hospitalized due to SARI at the PICU of $t$ Instituto Nacional de Salud del Niño (National Children's Hospital) in Lima, Peru. Real-time direct immunofluorescence and RT-PCR tests were performed for the diagnosis of respiratory viruses on tracheal aspirate or nasopharyngeal swab samples. Results. We included 117 patients. Median age was four months, $66 \%$ had comorbidity and $91 \%$ required mechanical ventilation. Respiratory virus monoinfection was identified in $47 \%$ and viral co-infection in $2.6 \%$, with the respiratory syncytial virus subtype A (RSV-A) being the most frequent. The median length of hospitalization was 21 days and $20(17 \%)$ patients died. An association was found between a history of chronic lung disease and RSV-A infection $(p=0.045)$, and between Down syndrome and influenza A virus infection $(p=0.01)$. After controlling for potential confounders, congenital heart disease (RR 3.1; $95 \% \mathrm{Cl}: 1.3-5.8, \mathrm{p}=0.002)$ and nosocomial infection $(\mathrm{RR} 2.6 ; 95 \% \mathrm{Cl}$ : $1.0-5.3, p=0.01$ ) were found to increase the risk of death in patients with SARI. Conclusions. RSV-A was the most common viral etiology in children under five hospitalized by SARI at the PICU. No association was found between viral infection and patient survival.
\end{abstract}

Keywords: Human Respiratory Syncytial Virus, Real-Time Polymerase chain reaction, Pediatric Intensive Care Units, Peru (Source: MeSH NLM).

\footnotetext{
Unidad de Cuidados Intensivos Pediátricos, Instituto Nacional de Salud del Niño. Lima, Perú

Centro Nacional de Salud Pública, Instituto Nacional de Salud. Lima, Perú

Universidad Nacional Federico Villarreal. Lima, Perú

Médico pediatra; ${ }^{\mathrm{b}}$ médico infectólogo; ${ }^{\mathrm{c}}$ fisioterapista cardiorrespiratório; ${ }^{\mathrm{d}}$ enfermera; ${ }^{\mathrm{e}}$ bióloga; ${ }^{\mathrm{f}}$ tecnólogo médico

Recibido: 23/11/2018 Aprobado: 08/05/2019 En línea: 28/06/2019
}

Citar como: Becerra M, Fiestas V, Tantaleán J, Mallma G, Alvarado M, Gutiérrez V, et al. N. Etiología viral de las infecciones respiratorias agudas graves en una Unidad de Cuidados Intensivos Pediátricos. Rev Peru Med Exp Salud Publica. 2019;36(2):231-8. doi: http://dx.doi.org/10.17843/rpmesp.2019.362.4081. 


\section{INTRODUCCIÓN}

Las infecciones respiratorias agudas graves (IRAG) continúan siendo la principal causa de morbilidad y mortalidad de la población pediátrica, constituyendo un reto importante para los servicios de salud a nivel mundial ${ }^{(1,2)}$. Según la Organización Mundial de la Salud (OMS), cerca de un millón de niños menores de cinco años fallecieron en el 2015 por neumonía, principalmente en los países de bajos ingresos ${ }^{(3)}$.

Los virus respiratorios son causa frecuente de las IRAG en niños menores de cinco años. Una revisión sistemática evidencia que una etiología viral fue identificada en el $50,4 \%$ de las IRAG, variando entre $48,7 \%$ en neumonías y $66,3 \%$ en bronquiolitis ${ }^{(4)}$. Entre los diferentes virus respiratorios identificados se ha establecido una fuerte asociación etiológica con el virus sincicial respiratorio (VSR), virus influenza, virus parainfluenza (VPI) y metapneumovirus humano ${ }^{(5)}$.

En Perú, las infecciones respiratorias agudas constituyen la principal causa de atención de los niños en los establecimientos de salud (35\%) y las IRAG continúan siendo la causa más frecuente de defunción ${ }^{(6)}$. Un estudio identificó la etiología viral en el 55\% de pacientes menores de cinco años con diagnóstico de neumonía ${ }^{(7)}$.

Desde 1990, las técnicas de biología molecular han tenido un notable desarrollo, las cuales debido a su alta sensibilidad y especificidad permiten la identificación de nuevos virus respiratorios y coinfecciones virales, aunque la utilidad clínica de estas pruebas diagnósticas aún se encuentre en evaluación ${ }^{(8,9)}$.

En relación con el tratamiento específico para infecciones por virus respiratorios, se recomienda brindar inhibidores de neuraminadasa a los pacientes con IRAG por influenza ${ }^{(10)}$; por lo cual, una identificación oportuna de agentes etiológicos virales en niños hospitalizados con IRAG resultaría de gran utilidad para monitorizar los virus respiratorios circulantes, reducir el uso de antibióticos y orientar las medidas de control.

En Perú no hay estudios publicados sobre la etiología viral en pacientes hospitalizados por IRAG en Unidades de Cuidados Intensivos Pediátricos (UCIP). El objetivo de este estudio es identificar los principales virus respiratorios causantes de IRAG en menores de cinco años hospitalizados en una UCIP y analizar las características clínicas de estos pacientes.

\section{MATERIALES Y MÉTODOS}

Estudio longitudinal prospectivo realizado en la Unidad de Cuidados Intensivos Pediátricos del Instituto Nacional

\section{MENSAJES CLAVE}

Motivación para realizar el estudio. Las infecciones respiratorias agudas son las causas más frecuentes de atención de niños en establecimientos de salud. Los casos graves requieren cuidados críticos y pueden ser producidos por virus o bacterias. Existe poca información sobre los virus que producen estos casos graves y como estos influyen en la evolución del paciente.

Principales hallazgos. El virus sincicial respiratorio fue identificado más frecuentemente en niños menores de cinco años hospitalizados por infección respiratoria aguda grave en una Unidad de Cuidados Intensivos Pediátricos, principalmente en aquellos que tenían una enfermedad pulmonar crónica.

Implicancias. El estudio contribuye con evidencias para orientar las medidas de prevención y control de las infecciones respiratorias agudas graves de causa viral.

de Salud del Niño (UCIP-INSN) ubicado en Lima, Perú. EI INSN es el principal hospital de referencia del país para la atención de pacientes pediátricos en el sector público. La UCIP-INSN tiene 15 camas que atienden aproximadamente 400 ingresos anuales $(50 \%$ por causa quirúrgica) con una tasa de mortalidad del $18 \%$. En general, se admiten pacientes que requieran cuidados críticos, con excepción de neonatos, pacientes oncológicos, quemados o posoperados de cirugía cardiaca, para quienes existen unidades especializadas en el INSN.

Se incluyeron en el estudio a niños menores de cinco años hospitalizados en la UCIP-INSN entre abril de 2012 y abril de 2014. Como en muchos estudios sobre infecciones respiratorias de etiología viral, usamos la definición de IRAG de la OMS: cuadro clínico agudo con historia de fiebre, tos y dificultad respiratoria que requiere hospitalización ${ }^{(11)}$. Se incluyeron también a aquellos casos que iniciaron cuadro clínico después de 48 horas de hospitalización (probable IRAG nosocomial).

Después de obtener el consentimiento informado de los padres o tutores, se obtuvo información de la historia clínica del paciente que incluía datos generales, antecedentes patológicos, diagnóstico clínico y score PRISM (siglas en inglés de Pediatric Risk of Mortality), puntaje predictivo de mortalidad que se calcula al momento del ingreso del paciente a la UCIP-INSN. Luego del alta o fallecimiento del paciente, se recopiló información sobre tiempo de uso del ventilador mecánico, tiempo de hospitalización en la UCIP y condición de egreso.

En el momento de ingreso a la UCIP, se obtuvo una muestra de aspirado traqueal en los pacientes con intubación endotraqueal o una muestra de hisopado nasal y faríngeo en los pacientes sin intubación ${ }^{(11)}$, las cuales fueron colocadas en tubos con medio de transporte universal (BD ${ }^{\mathrm{TM}}$, Nueva Jersey, EUA) y conservadas a temperatura de $2-8^{\circ} \mathrm{C}$ hasta 
su envío al Laboratorio de Referencia Nacional de Virus Respiratorios del Instituto Nacional de Salud (INS), donde fueron procesados mediante las siguientes técnicas de diagnóstico:

Inmunofluorescencia directa (IFD)

Se utilizó el kit comercial D³ Ultra 8 DFA(Diagnostic Hybrids, Inc.; Atenas, $\mathrm{OH}$ ) con anticuerpos monoclonales específicos conjugados con fluoresceína para la detección de antígenos de virus influenza $A$, influenza $B, V S R$, metapneumovirus humano, adenovirus (ADV), parainfluenza (VPI) 1, 2 y 3.

RT-PCR en tiempo real (qPCR) para virus influenza, VSR $y$ adenovirus

Para la identificación de virus ARN se utilizó QIAamp Viral RNA Mini Kit (QIAGEN; Hilden, Alemania) para la extracción de ARN viral en 140 uL de muestra y el kit comercial Super Script ${ }^{\circledR}$ III One-Step RT-PCR System with Platinum ${ }^{\circledR}$ Taq DNA Polymerase (Invitrogen; San Diego, CA) fue usado para la amplificación de 5 uL de ARN extraído utilizando termociclador Rotor-Gene Q; se usaron iniciadores y sondas específicas para la detección del gen de la hemaglutinina de virus influenza (AH1N1pdm09, AH3N2 y B), así como para la identificación de los genes de las proteínas $F$ y $G$ del VSR (subtipos A y B). Para la identificación de adenovirus se utilizó QIAamp DNA Mini Kit (QIAGEN; Hilden, Alemania) en 200 uL de muestra y la amplificación se realizó a partir de 5 uL de DNA extraído, se utilizaron iniciadores y sondas fluorescentes marcadas con FAM-BHQ1 que hibridan con la región conservada del gen hexon (kit preparado por ThermoScientific). No se realizó qPCR para identificar virus parainfluenza.

Finalmente, un diagnóstico de virus respiratorio fue establecido cuando la muestra resultó positiva por técnica de IFD y/o qPCR.

\section{ANÁLISIS ESTADÍSTICO}

El análisis descriptivo incluyó el cálculo de frecuencias y porcentajes para las variables cualitativas, así como el cálculo de la mediana y rango intercuartil (RIQ) para las variables cuantitativas. Para evaluar asociación entre las variables cualitativas usamos prueba de Chi cuadrado de Pearson o prueba exacta de Fisher, según corresponda. Para comparar la mediana de variables cuantitativas se usó la prueba no paramétrica $U$ de Mann-Whitney entre dos grupos o Kruskal-Wallis con prueba de comparación múltiple de Dunn entre los grupos según etiología viral. Realizamos un análisis de regresión logística para identificar los factores de riesgo de mortalidad, controlando por posibles factores de confusión, además, una prueba de bondad de ajuste del modelo fue realizada y los resultados fueron expresados en valor de riesgo relativo ( $R R$ ) con intervalos de confianza al 95\% (IC 95\%). Finalmente, se realizó un análisis de supervivencia de Kaplan Meier para comparar los grupos con una y ninguna etiología viral identificada. Para todos los análisis se estableció un nivel de significancia estadística (de 2 colas) de $5 \%$. Se usó el programa estadístico STATA versión 14.0 (College Station, TX: StataCorp LP).

\section{ASPECTOS ÉTICOS}

Los padres de los pacientes incluidos en el estudio otorgaron previamente consentimiento informado por escrito. Los procedimientos del estudio y los formatos de consentimiento informado fueron aprobados por los comités de ética en investigación del INSN e INS.

\section{RESULTADOS}

Durante el periodo de estudio se identificaron 120 pacientes menores de cinco años que cumplieron con los criterios diagnósticos de IRAG; no obstante, sólo fueron incluidos 117 pacientes en el estudio debido a que tres pacientes fueron reingresos.

\section{CARACTERISTIICAS CLÍNICAS DE LOS PACIENTES CON IRAG}

La mediana de edad de los pacientes fue de 4 meses (RIQ: 2-9 meses) y el $82 \%$ de los pacientes fueron menores de un año, con predominio del sexo masculino (61\%). Casi dos tercios de los pacientes (66\%) tenían alguna comorbilidad, siendo las más frecuentes: cardiopatía congénita (cianóticas y acianóticas), enfermedad pulmonar crónica (displasia broncopulmonar), enfermedad neurológica (síndrome convulsivo, epilepsia, parálisis cerebral) y dismorfismos (síndrome de Down) (Tabla 1). Los diagnósticos clínicos fueron: neumonía (56\%), síndrome coqueluchoide (22\%) y síndrome obstructivo bronquial (21\%). La mediana del score PRISM en el ingreso fue de 8 (RIQ: 5-12), la mediana del tiempo de hospitalización en la UCIP fue de 21 días (RIQ: $11-35$ días), el 91\% requirió ventilación mecánica con una mediana de 10,5 días (RIQ: 5,2-18,9 días) y 20 (17\%) pacientes fallecieron (Tabla 1 ).

\section{PACIENTES CON MONOINFECCIÓN VIRAL}

Por lo menos un virus respiratorio fue identificado en 58 pacientes (49,6\%) mediante técnica de IFD y/o qPCR, correspondiendo monoinfección viral a 55 pacientes (47\%). Se evidenció un mayor rendimiento de la técnica qPCR en comparación con la técnica IFD, incrementándose el porcentaje de diagnóstico en 31\% para el VSR, 46\% para el virus influenza A y $100 \%$ para ADV (Tabla 2). Para efecto del análisis estadístico, se agruparon los subtipos del virus influenza A y tipos de VPI para evaluar diferencias entre estos grupos de virus (Tabla 1). EI VSR subtipo A (VSR-A) fue la etiología más frecuentemente identificada (58\%), no se identificó VSR subtipo B; otros virus respiratorios 
Tabla 1. Características clínicas de los pacientes hospitalizados por infección respiratoria aguda grave (IRAG) según virus respiratorio identificado en la Unidad de Cuidados Intensivos Pediátricos del Instituto Nacional de Salud del Niño, $2012-2014$

\begin{tabular}{|c|c|c|c|c|c|c|}
\hline \multirow{3}{*}{ Características clínicas } & \multirow[b]{2}{*}{ Total $(n=117)$} & \multicolumn{4}{|c|}{ Monoinfección viral $(n=55)$} & \multirow{3}{*}{ Valor de $\mathbf{p}^{*}$} \\
\hline & & $\begin{array}{l}\text { VSR-A } \\
(n=32)\end{array}$ & $\begin{array}{c}\text { Influenza A } \\
(n=12)\end{array}$ & $\begin{array}{l}\text { Parainfluenza } \\
\qquad(n=6)\end{array}$ & $\begin{array}{l}\text { Adenovirus } \\
\quad(n=5)\end{array}$ & \\
\hline & $\mathrm{n}(\%)$ & $\mathrm{n}(\%)$ & $n(\%)$ & $n(\%)$ & $n(\%)$ & \\
\hline \multicolumn{7}{|l|}{ Edad (meses) } \\
\hline Mediana (RIQ) & $4(2-9)$ & $3(2-5,5)$ & $8(2-13,5)$ & $3,5(2-5)$ & $6(3-9)$ & 0,373 \\
\hline \multicolumn{7}{|l|}{ Sexo } \\
\hline Femenino & $46(39)$ & $9(28)$ & $6(50)$ & $1(17)$ & $3(60)$ & 0,341 \\
\hline Masculino & $71(61)$ & $23(72)$ & $6(50)$ & $5(83)$ & $2(40)$ & \\
\hline Comorbilidad $^{\dagger}$ & $77(66)$ & $22(69)$ & $8(67)$ & $2(33)$ & $4(80)$ & 0,674 \\
\hline Cardiovascular & $36(31)$ & $9(28)$ & $6(50)$ & $2(33)$ & $3(60)$ & 0,352 \\
\hline Pulmonar & $14(12)$ & $8(25)$ & $0(0)$ & $0(0)$ & $1(20)$ & 0,045 \\
\hline Neurológica & $10(9)$ & $2(6)$ & $1(8)$ & $0(0)$ & $0(0)$ & 0,946 \\
\hline Síndrome de Down & $11(9)$ & $0(0)$ & $4(33)$ & $1(17)$ & $0(0)$ & 0,010 \\
\hline \multicolumn{7}{|l|}{ Fuente de infección } \\
\hline Comunitaria & $76(65)$ & $24(75)$ & $5(42)$ & $4(67)$ & $5(100)$ & 0,102 \\
\hline Nosocomial & $41(35)$ & $8(25)$ & $7(58)$ & $2(33)$ & $0(0)$ & \\
\hline \multicolumn{7}{|l|}{ Diagnóstico clínico } \\
\hline Neumonía & $66(56)$ & $18(56)$ & $10(83)$ & $3(50)$ & $3(60)$ & 0,342 \\
\hline Síndrome coqueluchoide & $26(22)$ & $5(16)$ & $2(17)$ & $3(50)$ & $1(20)$ & \\
\hline Síndrome obstructivo bronquial & $25(21)$ & $9(28)$ & $0(0)$ & 0 & $1(20)$ & \\
\hline \multicolumn{7}{|l|}{ Tiempo de hospitalización } \\
\hline Mediana en días (RIQ) & $21(11-35)$ & $20,5(11-34)$ & $24,5(7-48.5)$ & $26(9-35)$ & $18(9-40)$ & 0,989 \\
\hline \multicolumn{7}{|l|}{ Score PRISM ${ }^{\ddagger}$} \\
\hline Mediana (RIQ) & $8(5-12)$ & $10(6-12)$ & $8(7-16)$ & $6.5(5-16)$ & $7(7)$ & 0,526 \\
\hline Ventilación mecánica & $106(91)$ & $31(97)$ & $11(92)$ & $3(50)$ & $5(100)$ & 0,066 \\
\hline Mediana en días (RIQ) & $10,5(5,2-18,9)$ & $10,6(6,4-21,6)$ & $10,5(4,7-21)$ & $6,6(2,8-12,8)$ & $14,7(14,2-31,5)$ & 0,208 \\
\hline Fallecimiento & $20(17)$ & $4(13)$ & $4(33)$ & $0(0)$ & $2(40)$ & 0,294 \\
\hline
\end{tabular}

identificados fueron: virus influenza A (22\%), VPI (11\%) y ADV (9\%). En la figura 1 se muestra la distribución de los casos según etiología viral y mes de ingreso a la UCIP, observándose un mayor número de casos de IRAG en los meses de junio y julio, y un mayor número de casos de VSR-A en los meses de abril, mayo y junio.

La mediana de edad fue mayor en los pacientes con infección por virus influenza A (7/12 tenían edad para recibir vacuna contra influenza, pero no estaban vacunados); no se encontró diferencia significativa entre los grupos de etiología viral según la edad y sexo.

En relación con el antecedente de comorbilidad, se observó una asociación entre la infección por VSR-A y el antecedente de enfermedad pulmonar crónica $(p=0,045)$, así como entre la infección por el virus influenza $A$ (específicamente influenza $A$ (H1N1)pdm09) y el síndrome de Down $(p=0,01)$; adicionalmente, la mitad de los pacientes fallecidos con infección por virus influenza A (2/4) presentaron síndrome de Down.

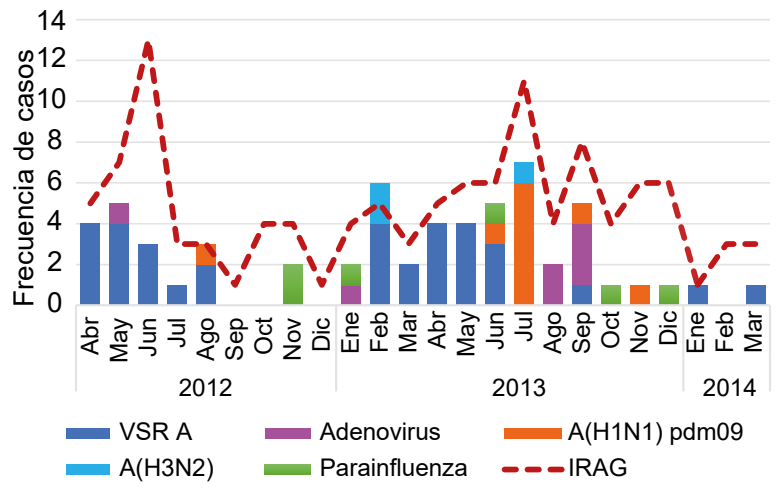

Figura 1. Distribución mensual de los casos de infección respiratoria aguda grave (IRAG) según etiología viral en la Unidad de Cuidados Intensivos Pediátricos del Instituto Nacional de Salud del Niño, 2012-2014 
Tabla 2. Identificación viral según técnica de diagnóstico en la Unidad de Cuidados Intensivos Pediátricos del Instituto Nacional de Salud del Niño, 2012-2014

\begin{tabular}{ccc}
\hline Identificación viral & $\begin{array}{c}\text { PCR en } \\
\text { tiempo } \\
\text { real }\end{array}$ & $\begin{array}{c}\text { Inmunofluorescencia } \\
\text { directa }\end{array}$ \\
\hline Monoinfección viral $(n=55)$ & & 24 \\
Virus sincicial respiratorio & $32^{*}$ & 7 \\
Virus influenza A & & - \\
\hline AH1N1pdm09 & 10 & - \\
\hline AH3N2 & 2 & 0 \\
\hline Adenovirus & 5 & 1 \\
\hline Parainfluenza 2 & $N R$ & 5 \\
\hline Parainfluenza 3 & $N R$ & \\
Co-infección viral ( $n=3)$ & & $\dagger$ \\
\hline Adenovirus/VSR-A & 2 & $\ddagger$ \\
\hline AH3N2NSR-A & 1 & \\
\hline
\end{tabular}

AH3N2: Virus influenza A (H3N2), VSR-A: Virus sincicial respiratorio subtipo A, NR: No se realizó qPCR para identificar virus parainfluenza

* Todos correspondieron a VSR-A

† Sólo en una muestra se identificó VSR

¥ Sólo se identificó virus influenza A

Para la mayoría de los virus respiratorios, la fuente de infección más frecuente fue la comunitaria, con excepción del virus influenza A; el $58 \%$ de los pacientes con infección por virus influenza A que ingresaron a la UCIP-INSN tuvieron probable origen nosocomial y todos estos casos fueron del subtipo A H1N1pdm09 (Tabla 1).

Un virus respiratorio fue identificado en el $52 \%$ (34/66) de pacientes con neumonía (VSR-A 53\%, virus influenza $A$ $29 \%$, VPI $9 \%$ y ADV $9 \%$ ), en el $42 \%$ (11/26) en síndrome coqueluchoide (VSR-A 45\%, virus influenza A 18\%, VPI $27 \%$ y ADV $9 \%$ ) y en el $40 \%$ (10/25) en síndrome obstructivo bronquial (VSRA 90\% y ADV 10\%). No encontramos asociación entre la etiología viral y la fuente de infección, el diagnóstico clínico, el tiempo de hospitalización en UCIP, score PRISM y uso de ventilación mecánica. No encontramos diferencias significativas en las características clínicas entre los pacientes con IRAG que tuvieron y no tuvieron una etiología viral identificada.

\section{PACIENTES CON COINFECCIONES}

Se identificó coinfección viral en tres pacientes (2,6\%) (Tabla 2) y coinfección virus-bacteria en nueve pacientes $(7,7 \%)$ (Tabla 3). EI VSR-A fue más frecuentemente identificado en ambos tipos de coinfección. No encontramos asociación con mayor tiempo de hospitalización y ninguno de estos pacientes falleció.

\section{ANALISIS DE SOBREVIDA}

En la mitad de los pacientes fallecidos con IRAG (10/20) se identificó una etiología viral: VSR-A (4/10), virus influenza A H1N1pdm09 (3/10), virus influenza A H3N2 (1/10) y ADV (2/10); ninguno de los pacientes con infección por VPI falleció. No se encontró diferencia significativa en la sobrevida según etiología viral, ni cuando se compararon los grupos de pacientes con IRAG que tuvieron y no tuvieron una etiología viral identificada.

Del total de pacientes con IRAG fallecidos, $18(90 \%)$ tenían antecedente de comorbilidad $(p=0,01)$ y $12(60 \%)$ correspondían a probable infección nosocomial $(p=0,01)$. Se identificaron como factores asociados a mortalidad: tener antecedente de enfermedad cardiovascular $(2,4$ veces más riesgo), síndrome de Down (2,2 veces más riesgo), probable infección nosocomial (1,8 veces más riesgo) y diagnóstico clínico de neumonía (5,7 veces más riesgo) (Tabla $\mathrm{N}^{\circ} 4$ ). En el análisis multivariado, encontramos que tener antecedente de enfermedad cardiovascular (RR: 3,4; IC 95\%: 1,5-6,0; $p=0,004)$ y probable infección nosocomial (RR: 2,9; IC 95\%: 1,2-5,4; $p=0,016$ ) continuaron siendo factores asociados a mortalidad en los niños menores de cinco años hospitalizados por IRAG en la UCIP-INSN.

Finalmente, un análisis de supervivencia de Kaplan Meier no evidenció diferencia significativa cuando se compararon los grupos de pacientes con IRAG que tuvieron y no tuvieron una etiología viral identificada (Figura 2).

Tabla 3. Identificación de coinfección virus y bacteria en la Unidad de Cuidados Intensivos Pediátricos del Instituto Nacional de Salud del Niño, 2012-2014

\begin{tabular}{|c|c|c|c|c|c|}
\hline Agente etiológico & VSR-A & VPI-3 & ADV & AH3N2 & $\begin{array}{l}\text { AH3N2 } \\
\text { VSR-A }\end{array}$ \\
\hline Bordetella sp & - & 2 & - & - & - \\
\hline Klebsiella pneumoniae & 2 & - & - & - & - \\
\hline Pseudomona aeruginosa & 2 & - & - & - & - \\
\hline Staphylococo aureus & - & - & - & - & 1 \\
\hline Stenotrophomonas maltophilia & - & - & - & 1 & - \\
\hline Streptococcus pneumoniae serotipo $25 \mathrm{~A}$ & - & - & 1 & - & - \\
\hline
\end{tabular}

VSR-A: Vírus sincicial respiratório subtipo A, VPI-3: Parainfluenza 3, ADV: Adenovirus,

AH3N2. Virus influenza A (H3N2) 


\section{DISCUSIÓN}

Aproximadamente la mitad de niños menores de cinco años hospitalizados por IRAG en la UCIP-INSN tuvieron infección con virus respiratorios, siendo concordante con publicaciones realizadas en otros países ${ }^{(4,5)}$. En general, las infecciones respiratorias agudas son la causa de atención más frecuente en la población pediátrica ${ }^{(1)} y$ muchos casos severos (IRAG) requieren atención en una UCIP, teniendo en cuenta que existen factores anatómicos y fisiológicos que explican una mayor susceptibilidad de los niños para presentar insuficiencia respiratoria en comparación con los adultos $^{(12)}$.

Son limitadas las publicaciones sobre virus respiratorios en una UCIP, un estudio realizado en Brasil encontró una proporción de $38,7 \%$ identificados mediante técnica de inmunofluorescencia indirecta ${ }^{(13)}$ y otro estudio realizado en Europa usando técnica de RT-PCR identificó virus respiratorios en $39 \%$ de los niños hospitalizados por IRAG en la UCIP ${ }^{(14)}$.

Las técnicas de biología molecular para el diagnóstico de virus respiratorios tienen actualmente una gran ventaja debido a su mayor sensibilidad y especificidad, permitiendo el diagnóstico de nuevos virus y coinfecciones. En este estudio, el uso de la técnica qPCR incrementó el rendimiento diagnóstico de virus respiratorios con respecto a la técnica IFD, principalmente para ADV $(100 \%)$ en forma similar a lo reportado en la literatura ${ }^{(15)}$
El virus respiratorio más frecuentemente identificado en el estudio fue el VSR (58\%), el cual fue hallado en el $90 \%$ de casos de síndrome obstructivo bronquial, $53 \%$ de casos de neumonía y $45 \%$ de casos de síndrome coqueluchoide. El VSR es la principal causa de hospitalización por neumonía y bronquiolitis en niños menores de cinco años a nivel mundial y estos resultados concuerdan con revisiones sistemáticas y metaanálisis publicados ${ }^{(4,5,16)}$. Aunque la

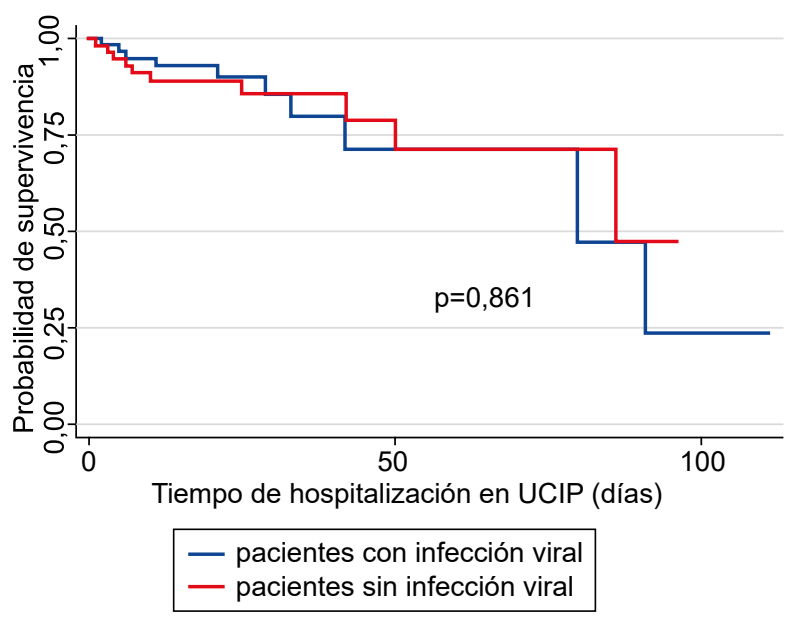

Figura 2. Análisis de supervivencia de Kaplan Meier entre los grupos que tuvieron y no tuvieron etiología viral identificada en la Unidad de Cuidados Intensivos Pediátricos del Instituto Nacional de Salud del Niño, 2012-2014

Tabla 4. Factores asociados a la mortalidad de niños hospitalizados por infección respiratoria aguda grave en la Unidad de Cuidados Intensivos Pediátricos del Instituto Nacional de Salud del Niño, 2012-2014

\begin{tabular}{|c|c|c|c|c|c|}
\hline Factor & $\begin{array}{l}\text { Vivos } \\
(\mathrm{n}=97)\end{array}$ & $\begin{array}{c}\text { Fallecidos } \\
(n=20)\end{array}$ & $\mathbf{R R}$ & IC $95 \%$ & Valor de $p$ \\
\hline Edad menor de 1 año & 81 & 15 & 0,63 & $0,26-1,52$ & 0,313 \\
\hline \multicolumn{6}{|l|}{ Sexo } \\
\hline Femenino & 38 & 8 & 1,00 & & \\
\hline Masculino & 59 & 12 & 0,97 & $0,43-2,19$ & 0,945 \\
\hline \multicolumn{6}{|l|}{ Comorbilidad } \\
\hline Cardiovascular & 24 & 12 & 3,38 & $1,51-7,54$ & 0,002 \\
\hline Pulmonar & 13 & 1 & 0,39 & $0,06-2,67$ & 0,292 \\
\hline Síndrome de Down & 6 & 5 & 3.21 & $1,24-6,25$ & 0,010 \\
\hline \multicolumn{6}{|l|}{ Fuente de infección } \\
\hline Comunitario & 68 & 8 & 1,00 & & \\
\hline Nosocomial & 29 & 12 & 2,78 & $1,24-6,25$ & 0,010 \\
\hline \multicolumn{6}{|l|}{ Diagnóstico clínico } \\
\hline Neumonía & 49 & 18 & 6,72 & $1,63-27,63$ & 0,001 \\
\hline Síndrome coqueluchoide & 25 & 1 & 0,18 & $0,03-1,31$ & 0,042 \\
\hline Síndrome obstructivo bronquial & 23 & 1 & 0,41 & $0,10-1,65$ & 0,173 \\
\hline \multicolumn{6}{|l|}{ Diagnóstico viral } \\
\hline VSR-A & 28 & 4 & 0,59 & $0,21-1,63$ & 0,288 \\
\hline Virus influenza A & 8 & 4 & 2,00 & $0,79-5,08$ & 0,165 \\
\hline Adenovirus & 3 & 2 & 1,75 & $0,50-6,06$ & 0,406 \\
\hline
\end{tabular}

VSR-A: Virus sincicial respiratorio subtipo $A$

$\mathrm{RR}=$ riesgo relativo 
circulación de los subtipos A y B ha sido demostrada en Perú ( ${ }^{17)}$, sólo identificamos el VSR-A; en la actualidad, no existe un consenso sobre la asociación entre el subtipo de VSR y severidad del cuadro clínico; sin embargo, un estudio reciente encontró que los niños con infección por VSR-A tuvieron mayor riesgo de requerir atención en una UCIP ${ }^{(18)}$. Por otro lado, existe evidencia de la estacionalidad de la circulación del VSR a nivel global, estableciéndose que la actividad de este virus comienza en los países del hemisferio sur entre los meses de marzo y junio ${ }^{(19)}$, similar a lo encontrado en el estudio.

Otro hallazgo importante fue que una proporción significativa de pacientes con enfermedad pulmonar crónica tenían infección por VSR. Una revisión sistemática encontró que diferentes condiciones crónicas o malformaciones congénitas están asociadas con un mayor riesgo de enfermedad grave y muerte en niños con infección por VSR ${ }^{(20)}$. De esta manera, la inmunoprofilaxis con palivizumab en niños con enfermedad pulmonar obstructiva crónica, cardiopatía congénita y prematuridad ha demostrado ser una alternativa segura y efectiva para reducir el riesgo de enfermedad grave por VSR ${ }^{(21)}$; sin embargo, su alto costo aún dificulta su uso en muchos países.

Se identificó virus respiratorios en el $42 \%$ de los casos con sindrome coqueluchoide, principalmente VSR-A y virus parainfluenza 3 (incluyendo coinfección con Bordetella pertussis en dos casos). Según la literatura, los virus respiratorios pueden ser identificados con frecuencia en niños con síndrome coqueluchoide. Un reporte de Brasil identificó virus respiratorios en $26 \%$ (VSR y virus parainfluenza 3) y coinfección de virus respiratorio con Bordetella pertussis en $5 \%$ de los niños hospitalizados por síndrome coqueluchoide ${ }^{(22)}$.

El virus influenza $A$ fue el segundo identificado con mayor frecuencia, principalmente el subtipo A (H1N1)pdm09, que coincidió con un brote epidémico, de este virus, entre junio y julio del $2013^{(23)}$, ninguno de estos pacientes había recibido vacuna contra influenza a pesar del antecedente de comorbilidad. Existe evidencia de un mayor riesgo de enfermedad grave en niños con comorbilidad que tienen infección por virus influenza A (H1N1)pdm09 (24). Se encontró que una proporción significativa de pacientes con infección por este virus tenían síndrome de Down, sin embargo, no se ha podido establecer que los pacientes con este síndrome tengan un mayor riesgo de enfermedad grave. Se plantea que la alta mortalidad observada en los reportes estaría relacionada a un mayor tiempo de hospitalización por las comorbilidades que frecuentemente presentan estos pacientes ${ }^{(25)}$. Sin embargo, es necesario resaltar la importancia de la vacunación contra influenza como medida de prevención en todos los niños con comorbilidad.
Las nuevas técnicas de diagnóstico por biología molecular también han permitido identificar con mayor frecuencia coinfecciones virales en niños con sintomatología respiratoria ( $1 \%$ a $40 \%)$, principalmente con VSR. Sin embargo, aún no existe consenso sobre un mayor riesgo de enfermedad grave por coinfección de virus respiratorios ${ }^{(26,27)}$ y generalmente este hallazgo dificulta el análisis individual de los virus. En este estudio identificamos coinfecciones virales $(2,6 \%)$ y coinfecciones virus-bacteria $(7,7 \%)$, principalmente con VSR; pero no evidenciamos asociación con mayor tiempo de hospitalización y ninguno de estos pacientes falleció.

Por último, en el estudio se observó un mayor riesgo de mortalidad de los pacientes con IRAG cuando tenían antecedente de cardiopatía congénita e infección nosocomial. Sin embargo, en forma similar a un reciente reporte ${ }^{(28)}$, no se encontró que la infección viral esté asociada a mayor mortalidad de los pacientes hospitalizados por IRAG en la UCIP.

Una gran limitación del estudio fue la falta de identificación de otros virus respiratorios como: rinovirus, metapneumovirus humano y bocavirus humano, lo cual podría haber reducido el número de niños con etiología indeterminada en el estudio e incluirse en el análisis. Sin embargo, aún es controversial el rol que estos virus puedan realmente tener como agentes etiológicos de IRAG ${ }^{(12)}$.

En conclusión, el VSR-A fue la etiología viral más frecuentemente hallada en menores de cinco años hospitalizados por IRAG en la UCIP-INSN. Los antecedentes de cardiopatía congénita e infección nosocomial incrementaron el riesgo de muerte en los pacientes con IRAG, pero no se evidenció asociación entre la infección viral y la sobrevida del paciente.

Agradecimientos: Los autores desean agradecer a los médicos, enfermeras y personal técnico de la Unidad de Cuidados Intensivos Pediátricos del Instituto Nacional de Salud del Niño que colaboraron en el presente estudio.

Contribución de los autores: MB, VF y JT participaron en la concepción y diseño del estudio; GM y MA participaron en la recolección de datos; $\mathrm{VG}, \mathrm{MH}$ y NR participaron en el procesamiento de las muestras biológicas; MB, VF y JT realizaron el análisis e interpretación de los datos; MB y VF redactaron el manuscrito preliminar. Todos los autores revisaron en forma crítica las versiones del manuscrito y aprobaron su versión final.

Fuentes de financiamiento: El estudio fue financiado por el Instituto Nacional de Salud del Niño y por el Instituto Nacional de Salud.

Conflictos de interés: Los autores declaran no tener conflictos de intereses en la publicación del estudio 


\section{REFERENCIAS BIBLIOGRÁFICAS}

1. Nair H, Simões EA, Rudan I, Gessner BD, Azziz-Baumgartner E, Zhang JSF, et al. Global and regional burden of hospital admissions for severe acute lower respiratory infections in young children in 2010: A systematic analysis. Lancet. 2013;381(9875):1380-90. doi:10.1016/ S0140-6736(12)61901-1.

2. Kyu HH, Pinho C, Wagner JA, Brown JC, Bertozzi-Villa A, Charlson FJ, et al. Global and National Burden of Diseases and Injuries Among Children and Adolescents Between 1990 and 2013. JAMA Pediatr. 2016;170(3):267-87. doi:10.1001/ jamapediatrics.2015.4276

3. World Health Organization. Pneumonia. Fact sheets. 2016 [Internet]. Geneva: WHO; 2018 [citado el 20 de octubre de 2018]. Disponible en: http://www.who. int/en/news-room/fact-sheets/detail/ pneumonia

4. Lukšić I, Kearns PK, Scott F, Rudan I, Campbell H, Nair H. Viral etiology of hospitalized acute lower respiratory infections in children under 5 years of age - a systematic review and meta-analysis. Croat Med J. 2013;54(2):122-34 doi:10.3325/cmj.2013.54.122.

5. Shi T, McLean K, Campbell H, Nair H. Aetiological role of common respiratory viruses in acute lower respiratory infections in children under five years: A systematic review and meta-analysis. J Glob Health. 2015;5(1):1-10. doi:10.7189/ jogh.05.010408.

6. Ministerio de Salud. Análisis de Situación de Salud del Perú [Internet]. Lima: MINSA; 2016. [citado 20 octubre 2018]. Disponible en: http://www.dge.gob.pe/ portal/docs/tools/asislocal15.zip

7. Padilla Ygreda J, Lindo Perez F, Rojas Galarza R, Tantalean Da Fieno J, Suarez Moreno V, Cabezas C, et al. Perfil etiológico de la neumonía adquirida en la comunidad en niños de 2 a 59 meses en dos zonas ecológicamente distintas del Perú. Arch Argent Pediatr. 2010;108(6):516-23. doi:10.1590/ S0325-00752010000600007.

8. Huijskens EG, Biesmans RC, Buiting AG, Obihara CC, Rossen JW. Diagnostic value of respiratory virus detection in symptomatic children using real-time $\mathrm{PCR}$. Virol J. 2012;9(1):276. doi:10.1186/1743422X-9-276

9. Wishaupt JO, Versteegh FGA, Hartwig NG. PCR testing for paediatric acute respiratory tract infections. Paediatr Respir Rev. 2015;16(1):43-8. doi:10.1016/j. prrv.2014.07.002.

10. World Health Organization. Influenza (Seasonal). Fact sheets. 2018 [Internet]. Geneva: WHO; 2019 [citado el 20 octubre de 2018]. Disponible en: https://www.who.int/en/news-room/ fact-sheets/detail/influenza-(seasonal)

11. World Health Organization. Global epidemiological surveillance standards for influenza [Internet]. Geneva, Switzerland; 2013. [citado 20 octubre 2018]. Disponible en: https://www.who.int/ influenza/resources/documents/WHO Epidemiological_Influenza_Surveillance_ Standards_2014.pdf?ua $=1$

12. Bontemps STH, Van Woensel JB, Bos AP. Acute viral lower respiratory tract infections in paediatric intensive care patients. Netherlands J Crit Care. 2013;17(2):13-8.

13. Straliotto SM, Siqueira MM, Machado V, Maia TMR. Respiratory viruses in the pediatric intensive care unit: Prevalence and clinical aspects. Mem Inst Oswaldo Cruz. 2004;99(8):883-7. doi:10.1590/ S0074-02762004000800017.

14. Moesker FM, Van Kampen JJA, Van Rossum AMC, De Hoog M, Koopmans MPG, Osterhaus ADME, et al. Viruses as sole causative agents of severe acute respiratory tract infections in children. PLoS One. 2016;11(3):e0150776. doi:10.1371/journal.pone.0150776

15. Kuypers J, Wright N, Ferrenberg J, Huang M-L, Cent A, Corey L, et al. Comparison of Real-Time PCR Assays with FluorescentAntibody Assays for Diagnosis of Respiratory Virus Infections in Children. J Clin Microbiol. 2006;44(7):2382-8. doi:10.1128/JCM.00216-06

16. Nair H, Nokes DJ, Gessner BD, Dherani M, Madhi SA, Singleton RJ, et al. Global burden of acute lower respiratory infections due to respiratory syncytial virus in young children: a systematic review and metaanalysis. Lancet. 2010;375(9725):154555. doi:10.1016/S0140-6736(10)60206-1.

17. Sovero M, Garcia J, Kochel T, LagunaTorres VA, Gomez J, Chicaiza W, et al. Circulating strains of human respiratory syncytial virus in Central and South America. PLoS One. 2011;6(8):e22111. doi:10.1371/journal.pone.0022111.

18. Laham FR, Mansbach JM, Piedra PA, Hasegawa K, Sullivan AF, Espinola JA, et al. Clinical Profiles of Respiratory Syncytial Virus Subtypes A and B among Children Hospitalized with Bronchiolitis. Pediatr Infect Dis J. 2017;36(8):808-10. doi:10.1097/INF.0000000000001596.

19. Obando-Pacheco P, Justicia-Grande AJ, Rivero-Calle I, Rodríguez-Tenreiro C, Sly P, Ramilo O, et al. Respiratory syncytial virus seasonality: A global overview. J Infect Dis. 2018;217(9):1356-64. doi:10.1093/ infdis/jiy056.
20. Manzoni P, Figueras-Aloy J, Simões EAF, Checchia PA, Fauroux B, Bont L, et al. Defining the Incidence and Associated Morbidity and Mortality of Severe Respiratory Syncytial Virus Infection Among Children with Chronic Diseases. Infect Dis Ther. 2017;6(3):383-411. doi:10.1007/s40121-017-0160-3.

21. Andabaka T, Nickerson JW, Rojas-reyes MX, Rueda JD, Bacic Vrca V, Barsic B. Monoclonal antibody for reducing the risk of respiratory syncytial virus infection in children (Review). Cochrane Database Syst Rev. 2013;(4). doi:10.1002/14651858 CD006602.pub4.Copyright

22. Ferronato AE, Gilio AE, Vieira SE. Respiratory viral infections in infants with clinically suspected pertussis. J Pediatr (Rio J). 2013;89(6):549-53. doi:10.1016/j. jped.2013.05.004

23. Boletin Epidemiologico 28 (del 07 al 13 de Julio de 2013). Incremento de la circulación de virus de influenza $\mathrm{A}(\mathrm{H} 1 \mathrm{~N} 1) \mathrm{pdm} 09$ en Lima Metropolitana y el Callao [Internet]. MINSA: Lima; 2013. Disponible en: http://www.dge.gob.pe/portal/docs/ vigilancia/boletines/2013/28.pdf

24. Chong CY, Tan NW, Menon A, Thoon KC, Tee NWS, Fu S. Risk factors for complicated influenza A (H1N1) 2009 disease in children. Ann Acad Med Singapore. 2013 May;42(5):232-6.

25. Tibby SM, Durward A, Goh CT, Thorburn K, Morris K, Broadhead M, et al. Clinical course and outcome for critically ill children with Down syndrome: A retrospective cohort study. Intensive Care Med. 2012;38(8):1365-71. doi:10.1007/ s00134-012-2589-x.

26. Lim FJ, De Klerk N, Blyth CC, Fathima P, Moore HC. Systematic review and metaanalysis of respiratory viral coinfections in children. Respirology. 2016;21(4):64855. doi:10.1111/resp.12741.

27. Rehder KJ, Wilson EA, Zimmerman $\mathrm{KO}$, Cunningham CK, Turner DA. Detection of multiple respiratory viruses associated with mortality and severity of illness in children. Pediatr Crit Care Med. 2015;16(7):e201-6. doi:10.1097/ PCC. 0000000000000492 .

28. Hon KL, Luk MP, Fung WM, Li CY, Yeung HL, Liu PK, et al. Mortality, length of stay, bloodstream and respiratory viral infections in a pediatric intensive care unit. J Crit Care. 2017;38:57-61. doi:10.1016/j. jcrc.2016.09.019.

Correspondencia: Victor Fiestas Solórzano Dirección: Instituto Nacional de Salud, Jr. Cápac Yupanqui 1400, Código postal 15072. Lima, Perú

Correoelectrónico: vicfiso@yahoo.es 